\title{
David Oliver: Doughnut deliveries, hospital staff, and the pandemic
}

\author{
David Oliver consultant in geriatrics and general internal medicine
}

Berkshire

I've spent three decades working in acute hospitals. The stress, relentless pace, long shifts with irregular hours, and lack of access to fresh food around the clock have always seen staff use high calorie processed food for comfort, mutual support, and bonding.

Whether it's takeaways, sweets, biscuits, cakes, or crisps-often bought by one member of the team for the rest to help them through a shift or donated by grateful patients and left on the ward-we're rarely far from impromptu snacking opportunities. Even when it comes to canteens offering healthy options, busy workers often gravitate to the comfort of chips, pizzas, burgers, or fried food. Go to the League of Friends shop, and it's often full of home baked cakes.

During the covid-19 pandemic our levels of stress, distress, and fear have risen, and food and fizzy drinks have featured among our coping strategies. A well intentioned public has supported us by volunteering, clapping each Thursday night, and sending gifts, including food. Some food companies and local shops have also donated, partly in the spirit of solidarity and support but in some cases aware of the positive publicity and marketing opportunities. In many ways, I wish they wouldn't: NHS staff have steady, secure employment and income, whereas so many other parts of the economy and other groups of workers are in economic strife. They, or food banks or homeless people, might be better recipients.

\section{Public health message}

The issues came to a head in April, when a picture was tweeted of 1500 Krispy Kreme doughnuts being delivered to hospital clinical teams in Barnet, north London. The cardiologist Aseem Malhotra-an author of diet books and campaigner for low carb diets ${ }^{1}$ - was one of several medics on social media who condemned this as a blatant marketing stunt. ${ }^{2} \mathrm{He}$ and others argued that it sent a very bad message considering the highly processed, calorie dense nature of the product. And, with emerging data linking obesity to far higher morbidity and mortality in people who contract covid- $19,{ }^{3}$ he said that the public health message, from clinicians and managers who should be setting an example, was poor.

Malhotra then appeared on Good Morning Britain arguing that Boris Johnson, having contracted coronavirus, had become far more unwell than other slimmer political figures and that his obesity and lack of fitness were to blame. ${ }^{4}$ I found his comments about the prime minister and their speculative nature inappropriate, given Johnson's very recent status as an NHS patient.

As for the doughnuts, a wealth of evidence clearly shows that the ready availability of cheap, high calorie processed foods and sugary drinks - coupled with bigger portion sizes, a lack of readily available and affordable alternatives, and advertising — creates an obesogenic environment, often meaning that individual choice and agency are compromised..$^{56}$

Obesity among NHS staff will to an extent reflect a wider population problem, and it probably doesn't look good for so many of us to be overweight; nor is it ideal for wellbeing and sickness rates. In 2015 NHS England's chief executive, Simon Stevens, urged the NHS to "put its own house in order," including banning on-site junk food retailers and providing exercise classes, ${ }^{7}$ and in 2017 he announced plans to reduce the sale of high calorie processed foods and sugary drinks in hospitals. ${ }^{8}$ In 2018 the Nursing Times reported his claims of an average daily calorie reduction of 600 among hospital staff, although I've yet to see the data or the internal report he alluded to. ${ }^{9}$

I support the need for more healthy food options for hospital teams, more refrigerated storage for home cooked healthy meals, and chances to take proper breaks rather than eating on the hoof, with work based access to exercise classes, discounted gyms, group activities, sports, and cycle storage with on-site shower and changing facilities.

Ultimately, however, busy and stressed staff having the occasional free doughnut or take-out pizza in the middle of a pandemic is a distracting side issue. In the short term, our morale matters as much as our waistline, and besides, people aren't idiots. We know full well that processed food is bad for us: as 
health professionals, we see the effects daily. What we don't need is lectures. Give us a break. And let us eat cake.

Competing interests: See bmj.com/about-bmj/freelance-contributors.

Provenance and peer review: Commissioned; not externally peer reviewed.

Dr Aseem Malhotra. http://doctoraseem.com/.

2 Malhotra A. Twitter. 22 Apr 2020. https://twitter.com/DrAseemMalhotra/status/ 1252861958652452864

3 Obesity found to increase COVID-19 severity. Diabetes Times 2020 Apr 28. https:// diabetestimes.co.uk/obesity-found-to-increase-covid-19-severity/.

4 Good Morning Britain. Twitter. 28 Apr 2020. https://twitter.com/GMB/status/ 1255024641594347521
5 O'Rahilly S. Harveian Oration 2016: some observations on the causes and consequences of obesity. Clin Med (Lond) 2016;16:551-64. 10.7861/clinmedicine.16-6-551. https://www. ncbi.nlm.nih.gov/pmc/articles/PMC6297326/. 27927821

6 Townshend T, Lake A. Obesogenic environments: current evidence of the built and food environments. Perspect Public Health 2017;137:38-44. https://journals.sagepub.com/doi/ abs/10.1177/1757913916679860. 10.1177/1757913916679860 28449616

7 NHS England. £5million plan to improve the health of NHS staff. 2 Sep 2015. https://www. england.nhs.uk/2015/09/improving-staff-health/.

8 National Health Executive. NHS England cracks down on sale of unhealthy foods in hospitals. 16 Oct 2017. http://www.nationalhealthexecutive.com/Robot-News/nhs-englandcracks-down-on-sale-of-unhealthy-foods-in-hospitals.

9 Ford S. Curb on unhealthy food sales has "cut NHS calories by 600 million." Nursing Times 2018 Apr 6. https://www.nursingtimes.net/news/hospital/curb-on-unhealthy-foodsales-has-cut-nhs-calories-by-600-million-06-04-2018/.

Published by the BMJ Publishing Group Limited. For permission to use (where not already granted under a licence) please go to http://group.bmj.com/group/rights-licensing/ permissions 